\title{
Continuity of some Nabataean legal practices during the Late 19th - Early 20th century: a study in the light of unpublished deeds of sale from Wādì Mūsā, southern Jordan
}

\section{Zeyad al-Salameen}

United Arab Emirates University

\section{Hani Falahat}

Department of Antiquities of Jordan

\begin{abstract}
The epigraphic materials from the Ancient Near East and Syria show the continuity of legal traditions from an early period $^{1}$ and show the extent to which the ancient inhabitants of this area were able to protect their own possessions and how they regulated their use, as well as defining ownership rights according to specified codes enforced by laws ${ }^{2}$.
\end{abstract}

Despite the huge archaeological legacy left by the Nabataeans, their legal texts are relatively limited and they include some of the Hegra tomb inscriptions, the legal inscription uncovered in the Winged lion temple in Petra and the Wādì Habra papyri which

${ }^{1}$ For further details regarding this issue see R. WestbroOK, $A$ History of Ancient Near Eastern Law, Volume 1, Brill, Leiden, 2003; R. WeSTBROOK, R. JASNOW, Security for Debt in Ancient Near Eastern Law. Brill, Leiden, 2001.

2 These materials are of great significance since they shed light on the economic situation, social organisation and even daily life, matters which are not comprehensively covered in historical chronicles. 
represent direct witness to the high level of legal system ${ }^{3}$. Nabataean funerary inscriptions in Hegra, which are to be dated mostly to the first century AD, mention details about tomb's ownership and list the names of individuals who are permitted to be buried within. Some of these inscriptions hints to the existence of a local traditional law which is expressed in the form hlyqt which means literary "according to the nature, like". The word occurs also in the Nabataean papyri in different legal contexts such as hlyqt ' $m l$ “customary law of work" and hlyqt zbny' wbr'wn' dy mt[k]tbt Ilm "the customary law of purchases and clearances which are writ[t]en forever" ${ }^{\prime \prime}$. The second piece of evidence for the study of Nabataean law is the legal inscription that was found in the Winged Lions Temple at Petra ${ }^{7}$ refers to taxes paid to priests.

The major source for the studying of Nabataean legal practices and traditions are the Wādī Habra papyri, which are dated to the first and second centuries AD consist of fragmentary documents discovered in early 1960 in the so-called cave of letters and provide significant information on Nabataean agriculture, legal practices as well as daily life activities.

Historical chronicles tend to be virtually silent and do not provide us with details regarding the Nabataean law and the only hint is found in the Geography of Strabo who mentioned that his friend Athenodorus had been to Petra and found "many Romans and many other foreigners sojourning there, and that he saw that the foreigners often engaged in litigation, both with one another and with the natives, but that none of the natives prosecuted one another and that they in every way kept peace with one another" ${ }^{\prime \prime}$ . He wrote also that the Nabataeans would "publicly fine anyone who diminishes his possessions and confer honors to anyone who has increased". "The Babatha archive sheds new light on the importance of Petra in legal affairs and proves Strabo's statement.

\footnotetext{
${ }^{3}$ M. AbDElazIZ, «Notes on the Nabataean Legal System», in Dirasat, Human and Social Sciences 32 (2005), p.189-199.

${ }^{4}$ J. Healey, The Nabataean Tomb Inscriptions of Mada'in Salih. Oxford University Press, Oxford, 1993, 1; 8; 19

${ }^{5}$ J. HoftiJzer and K. JONGELING, Dictionary of the North-West Semitic Inscriptions. Brill, Leiden, 1995, 374 (hereafter cited as DNWSI).

${ }^{6}$ P.Yadin 3, line 40. This is the refreence to the papyrus in : Y. YADIN, J. Greenfield, A. YARDENI, B. LEVINE, The Documents from the Bar Kokhba Period in the Cave of Letters: Hebrew, Aramaic and Nabatean-Aramaic Papyri. Israel Exploration Society, Jerusalem, 2002. (Reference hereafter will be made to the number of the papyrus in this book).
}

${ }^{7}$ PH. Hammond, D. JOHNSON, R. JONES, «A Religio-Legal Nabataean Inscription from the Atargatis/Al-'Uzza Temple at Petra». in Bulletin of the American Schools of Oriental Research 263 (1986), p. 77-80.

\footnotetext{
${ }^{8}$ Geography of Strabo XVI.4.21.

${ }^{9}$ Geography of Strabo XVI.4.26.
} 
These documents refer to regular visits to and from Petra for the boule of Petra was involved in legal and financial affairs throughout the Petra administrative region ${ }^{10}$.

Nabataean archaeological remains uncovered in various regions have revealed strong evidence for Nabataean cultural continuity beyond the second century and at least to the fifth century $\mathrm{AD}^{11}$. Nabataean fine ware production, for example, continued well beyond the second century $\mathrm{AD}$, perhaps as late as the fourth and fifth centuries $\mathrm{AD}^{12}$. Some scholars see that there is no continuity of the Nabataean legal practices. Healey concludes that 'much of this legal tradition survived in northern Arabia into the Byzantine and early Islamic periods. The potential of this material in relation to the study of the historical roots of Islamic law is considerable"13. This is true as we shall demonstrate in this paper and as Cotton concluded from the study of the papyrological Greek evidence in the Petra papyri which confirm a continuity of Nabataean law during the Byzantine period ${ }^{14}$.

Our understanding of the Nabataean law has been enhanced after the publication of a number of papyri. In 1951 or 1952 the first known Nabataean papyri were discovered in Wādī Seiyāl. It is a redemption document dated c. AD 60. Father J. Starcky published this contract for the first time in $1954^{15}$. Between 1961-62 the Israel Exploration Society headed by Y. Yadin carried out an expedition in Wādī Habra (Nahal Hever), on the western side of the Dead Sea, about four and a half km south of 'Ain Gedi, and they found various remains consisting mainly of skeletons, artefacts, and letters sent by Bar Kokhba, in addition to other docu-

${ }^{10}$ N. LEWIS, Y. YADIN, J. GREENFIELD, The Documents from the Bar Kokhba Period in the Cave of Letters: Greek Papyri. Israel Exploration Society, Jerusalem, 1989, p. 14, 23, 25.

${ }^{11}$ K. D. POLITIS, «Nabataean Cultural Continuity into the Byzantine Period», in K. D. Politis (ed.), The World of the Nabataeans. Volume 2 of the International Conference 'The World of the Herods and the Nabataeans' held at the British Museum, 17-19 April 2001, Stuttgart, 2007, p.187-200.

${ }^{12}$ P. J. PARR, «Pottery, People and Politics», in P. R. S. MoOreY and P. J. PARR (eds.), Archaeology in the Levant, Warminster, 1978, p 203-209; K. 'AMR, "Beyond the Roman Annexation: The Continuity of the Nabataean Pottery Tradition", Studies in the Histroy and Archaeology of Jordan, 2004, p. 8, 237-245.

13 J. HeALEY, "Sources for the Study of Nabataean Law», New Arabian Studies 1 (1993), p. 210.

${ }^{14}$ H. CotTon, "Continuity of Nabataean Law in the Petra Papyri: A Methodological Exercise». in H. M. CotTon, R. G. Hoyland, J. J. PriCe, D. J. WASSERSTEIN (eds.), From Hellenism to Islam Cultural and Linguistic Change in the Roman Near East. Cambridge University Press, Cambridge, 2009, p. 154-174.

15 J. STARCKY, «Un contrat nabatéen sur papyrus», in Revue Biblique 61 (1954), p. 161-81. 
ments found particularly in Cave D the so-called, the Cave of Letters $^{16}$. In this cave, about thirty-five Greek, Aramaic and Nabataean documents were uncovered. Nine of these contain signatures and subscriptions in both Greek and Nabataean ${ }^{17}$. Six Nabataean documents were among this hoard. The importance of these papyri is that they are distinguished not merely by their content and size, since they are longer than the Nabataean tomb inscriptions found in Hegra, but because they also help to elucidate the contents of these inscriptions, especially those dealing with the ownership of the tombs, rights of burial, inheritance rules and fines imposed for violating what was inscribed on the tomb. Additionally, these documents help to enhance our understanding of the Nabataean legal traditions and practices during the last decades of the reign of the last Nabataean king Rabel II (AD 70-106) and the early years of the Provincial Arabia. These documents were written in ink on varying sizes of papyrus and the largest one measures $14.2 \times 81 \mathrm{~cm}^{18}$. Two of them (P. Yadin 2, 3) were written twice, adopting the so-called double document style. This type of commercial contracts was common and occurred frequently in the Aramaic, Greek and Hebrew first and second century BC legal and commercial papyri ${ }^{19}$. In these double documents the contract is written out twice on the same sheet one above the other and when the papyrus is rolled up the inner version is sealed to be protected against alteration and the outer version remains accessible ${ }^{20}$.

As far as their contents is concerned, these deeds can be classified into the following types a debenture ${ }^{21}$, three sale contracts ${ }^{22}$, a guaranty $^{23}$, a tenancy agreement ${ }^{24}$ and a waiver ${ }^{25}$.

All of these papyri are of vital significance for the student of the final years of the Nabataean kingdom and the first years of the Eparchy. Most of the Nabataean documents are dated to the reign of Rabel II, whereas the Greek documents cover the period AD 109/10-132. They shed light on the administrative divisions in the area immediately after the annexation. These administrative divisions and subdivisions might have been inherited by the Ro-

${ }^{16}$ Y. YADIN, «Expedition D- The Cave of the Letters». in Israel Exploration Journal 12 (1962), p. 227-57; N. Lewis, Y. Yadin, J. Greenfield, p. 3.

${ }^{17}$ Y. YADIN, p. 229.

${ }^{18}$ Y. Yadin, J. GREenfield, A. Yardeni, B. LeVIne, p. 173.

${ }^{19}$ N. LeWIS, Y. YAdin, J. GREENFIELD, p. 8.

${ }^{20}$ N. LEWIS, Y. YADIN, J. GREENFIELD, p. 8.

${ }^{21}$ P. Yadin 1.

22 P. Yadin 2, 3, 5.

${ }^{23}$ P. Yadin 4.

24 P. Yadin 6.

${ }^{25}$ P. Yadin 9. 
mans from the Nabataeans. There are two main administrative divisions attested in the Greek documents of Babatha: Petra and Rabbathmoab. Petra was the main capital of the Nabataean kingdom, and the first capital of the Provincia Arabia, or at least the major provincial city in the southern Levant. It seems from the documents that Petra did not lose its importance immediately after the annexation ${ }^{26}$. It was described in the texts as the district where Zoar was located ${ }^{27}$.

It is apparent from the contents of these documents, both the inscriptions and the papyri, that they formed a continuous part of the Ancient Near Eastern and Syrian common law. Although there are some scholars who assume that there was no continuity or traces of the Neo-Babylonian or the Neo-Assyrian legal traditions in the Aramaic papyri ${ }^{28}$, it has become clear from the arguments of Muffs that the Aramaic and Levantine legal traditions owed much to the Assyrians ${ }^{29}$. He says: "The ancient Near East was characterized by a remarkable cultural continuity. Norms didn't die; they were simply transformed into a new linguistic garb and in their new form continued their functions as of old"30.

The Nabataean documents are similar to other ancient Near Eastern legal documents found in the area and some of the phrases and locutions are common in these documents.

\section{Wādī Mūsā during the late 19th early 20th centuries}

Before we precede it is useful to shed some light on the history of Wādī Mūsā during the 19th and 20th centuries. The Swiss explorer Burckhardt ${ }^{31}$ visited Petra and stayed in Wādī Mūsā in 1812 and his notes and observations are preserved in his book entitled Travels in Syria and the Holy Land. He says that the town of Wādī Mūsā "is surrounded with fruit trees of all-kinds, the

${ }^{26}$ Petra was the main city in the Provincia Arabia that was involved in legal and juridical affairs. Although Nabataea lost its political independence in 106 $\mathrm{AD}$, it remained a key centre of activity. A poem in Dionysius Periegetes composed at the beginning of the second century AD (immediately after the annexation) mentions "the rich ones called Nabataioi" who lived "beyond the slopes of Libanos" J. RETSÖ, The Arabs in Antiquity: Their History from the Assyrians to the Umayyads. Routledge, London, 2003, p. 305.

${ }^{27}$ N. LEWIS, Y. YADIN, J. GREENFIELD, number 16, line13-14.

${ }^{28}$ R. YARON, Introduction to the Law of the Aramaic Papyri. The Clarendon Press, Oxford, 1961, p.122.

${ }^{29}$ Y. MUFFs, Studies in the Aramaic Legal Papyri from Elephantine. Brill, Leiden, 1969, p. 13.

${ }^{30}$ Y. MUFFs, p.13.

${ }^{31}$ Johann Ludwig Burckhardt was a Swiss explorer (1784-1817). He visited Egypt, Syria and Arabia between 1809 and 1813 and published some books about his travels including Travels in Syria and the Holy Land. He died and buried in Egypt. 
produce of which is of the finest quality. Great quantities of the grapes are sold at Gaza, and to the Bedouins...They pay tribute to the Howeytat and carry provisions to the Syrian pilgrimage at Maan, and to the Egyptian pilgrims at Aqaba. They have three encampments of about eighty tents each. Like the Bedouins and other inhabitants of Sherah they have become Wahabis, but do not at present pay any tribute to the Wahabi chief" ${ }^{\prime 32}$.

Between 1838-1839 the Egyptian government sent a party of troops to Petra. Kinnear says that after the party departed Aqaba they entered Wādī Mūsā without opposition but without seeing a single peasant. Kinnear talks about Petra saying "for several days the valley appeared to be entirely deserted, and, but for the little cultivated spaces among the ruins as utterly desolate as if it had remained for ages unoccupied" and the party returned without achieving any success" ${ }^{\prime 3}$. It seems that the party did not encounter any people here as the troops did not find any person. It is most likely that the dwellers during this attack take refuge in a hidden and unknown place. It is worthy of saying that it was the custom of the inhabitants of the area to retreat and hide themselves when they were attacked, taking refuge in an area that was not known to foreigners. This happened during the Nabataean period. Diodorus and in referring to the Seleucid attack on the Nabataeans says "They -the Nabataeans- are exceptionally fond of freedom; and whenever a strong force of enemies comes near, they take refuge in the desert" ${ }^{\prime 34}$.

By the end of the 19th and the beginning of the 20th centuries the Ottomans undertook several initiatives to protect the southern part of Jordan from the British expansion which reached Egypt. Therefore, they constructed the Hejaz railway with subbranches leading to Aqaba, Ras an-Naqab and Shoubak. During the Late Ottoman period, Wādī Mūsā was administratively a directorate Mudyriah which was attached through Maan District to the Wilayat of Syria. Nahiyat Wādī Mūsā, which was established in 1911 and was attached to Maan District. During this year an administrative building Saraya was constructed in Wādī Mūsā ${ }^{-35}$. During the Great Arab Revolt, Wādī Mūsā witnessed one of the

32 J. BurCKHARDT, Travels in Syria and the Holy Land. London, Palestine Exploration Fund, 1930, p. 433.

33 J. Kinnear, Cairo, Petra, and Damascus, in 1839. With remarks on the government of Mehemet Ali, and on the present prospects of Syria, J. Murray, London, 1841, p.162-162.

${ }^{34}$ Diodorus SiCulus, Library of History, Loeb Classical Library. Cambridge, MA.: Harvard University Press, 1935, II, 48.

35 M. AL-TARAWNEH, Tarñkh Minfaqat al-Balqa'a, Ma<an wal-Kerak (1864-1918). Published by the Ministry of Culture, Amman, 1992, p. 304 (in Arabic). 
decisive confrontations with the Turkish army which led consequently to the victory of the Arabs and their allies ${ }^{36}$.

After the First World War (1918-1921) the whole Levant was divided into military areas, and Transjordan was covering the Eastern part which extended between Maan in the south and the Syrian borders in the north, and this region was under the rule of King Faisal. During the early 1920s the District of Maan-Aqaba was considered as a part of the Kingdom of Hejaz, and after two years, the area under consideration became part of the Transjordan Emirate when the government appointed an administrative governor to Wādī Mūsā and Shoubak ${ }^{37}$.

During the 19th and 20th centuries, Wādī Mūsā was inhabited by the Layāthneh who are broken into four major tribes: 'Baydīyeh, 'Alāyā, Banī 'Ațā and esh-Shrūr and these were divided into sub-tribes. These were originally semi-nomads and settled peasants. The origin of these Layāthneh is still a questionable matter. This has been discussed in details by some researchers ${ }^{38}$.

The Layāthneh were mixed agro-pastoralists who used initially to live in tents and caves, and later on, probably by the end of the 18th century, they chose to construct their villages and houses in the places of the ancient human settlements that were one day inhabited. They were directly involved in semi-transhuman animal husbandry and agriculture. Their main source of income was based on agriculture and husbandry. Gertrude Bell who visited Wādì Mūsā on March 1900 said that the inhabitants of Wādī Mūsā "had not so much as milk" "39. She mentions in her diaries that "the village of Wadi Mousa set in gardens and fruit trees" 40 .

36 B. Al-MAJALI, al-Masarat al-<askarñyah lethwarah al-<arabñah alKubre. Al-Hussein Bin Talal University, Maan, 2003, p. 143-155.

${ }^{37}$ M. Al-Mathy, S. Al-MousA, Tarñkh al-Ordon fĩ al-Qarn al-<Shrñn. Maktabat al-Mo...taseb, Amman, 1988, p. 248-252 (in Arabic).

${ }^{38}$ For further discussion see M. NAWAFLEH, Liwa $>$ al-Batre $>$ : Al-Ardh wal-Insan. Published by the Ministry of Culture, Amman, 2004, p. 84-85 (in Arabic).

${ }^{39}$ Letter dated to $29 / 03 / 1900$.

40 (Diary 29/03/1900). (www.gerty.ncl.ac.uk). This website is the only available source that contains all the unpublished diaries, letters, photographs and archives of Gertrude Bell. 


\section{The Wādī Mūsā Deeds of Sale}

Let us now turn to the second part of our discussion, that are the documents collected by Hani Falahat from Wādī Mūsā and dated to the late 19th early 20th centuries. These include deeds of sale, marriage contracts, debentures, tenancy agreements, receipts and other types of personal agreements. What concerns us here is the deeds of sale. This collection of the sale contracts has similarities with the Nabataean papyri and all is written in Arabic in the cursive scripts nskh. They resemble the Nabataean legal documents uncovered in the Wādī Habra area in terms of the general form and style in addition to the contents as we shall see below.

Form and structure of the Wādī Mùsā Legal Documents Similarities with the Nabataean documents.

Ownership, sale and transfer of properties were normally documented in witnessed contracts. It is clear that the pattern of writing the late ottoman deeds from Wādī Mūsā depends on the type of the document. Interestingly, these documents share similarities with the Nabataean legal deeds uncovered in the Wādī Habra area and the Greek documents which have been uncovered in the Byzantine church at Petra ${ }^{41}$.

It should be noted that the documents collected from Wādī Mūsā share three major characteristics and these are:

1) The documents were written in hand, black ink with some spelling mistakes. Parts of some words are written at the end of the line and continued at the beginning of the second line.

2) There is a special symbol for every scribe. This could be observed after comparing scripts of documents headed with the same symbol.

3) Contrast to the Nabataean deeds of sale, there is no opening formula in the Wādī Mūsā documents which is usually a short sentence introducing the contents of the document. This is common in the ancient near eastern and ottoman texts.

4) Two types of currencies were referred to in these contracts. The Ottoman Majī $\overline{1}$ was still in use in the region after the collapse of the Ottoman Empire. The Majīi $\overline{1}$ was a silver Ottoman coin worth one-fifth of a Turkish golden pound, or twenty piasters. It was introduced by Sultan 'Abd al-Majīd (AD 1839-1861). The Palestinian pound, Junayh Filașțīni also was used and this was the currency of the British Mandate of Palestine and was used in Jordan till 1949.

\footnotetext{
${ }^{41}$ See for example H. COTTON, p. 154-174.
} 
A thorough study of the collected legal documents shows that the legal documents share the following characteristics with the Nabataean legal documents:-

\section{a) Identification of the parties.}

Both types of deeds include identification of the owner and purchaser of the property, who are specified by their given names, by that of their father and their tribes. There are always two parties in every contract and sometimes an authorized man can perform on behalf of a group or tribe. P.Yadin 2, for example, says "This (same) Sheadallah[i] has purchased with silver, (in the amount of) selas seventy-five [. And this, the entire price] of the[es]e [purchas]es, has been receiv[ed] by [me, I,] this (same) Shallum, the fixed sale price in $\mathrm{f}[\mathrm{u}] \mathrm{nds}$ ". In document 3 from Wādī Mūsā there are two parties: the first one is Mğanam bin Ğānim and the second party is Mūsā bin Sālim eț-Ṭwaisī and both are from the inhabitants of Wādī Mūsā.

\section{B) The contents.}

This part contains specifications of the landholding, which is specified normally according to its kind and location. The boundaries of the property are strictly delineated as neighbors are usually referred to by personal names. In Document 2 the seller states that "I sold my portions in the lands of the mosque which is bordered to the east by 'Ațallhah eț-Twaisī and reached (the land) of my brother Ibrahim and to the north (the land) of "Ațallhah, to the east is the public road, and to the south 'Isā eț-Ṭaisī and Ibrāhīm, and this sale includes various trees". The tradition of the delineation of the conveyanced or sold properties or the division of properties according to the adjoining surroundings in four directions goes back to the Akkadian ${ }^{42}$. The Nabataean documents delimited the properties according to the surrounding areas. In P. Yadin 2, for example, the sold property is described according to the surrounding areas and its boundaries $\left(T^{3} / 4 \mathrm{mmy} h\right)$ which are given as follows: to the east of the road and to the west of the houses of Tha, daughter of 'Abdharetat, to the south is the land of Rabel and to the north is the swamp.

\section{c) Identification of the sold property.}

This part includes the parts and things that are included in the sale. In P.Yadin 2 the sale includes "That [ga]rden, [all of it, within all (of)] its [bounda]ries, and all that belongs to this (same) 'by'dn [within] it, by inheritors'-right and (by) permission, and (including the) boundary and plot, and (according to) a valid and a sound (document), and a plot (?) [and (the) boun]dary (?), and a concealed or unconcealed (document); and...and...[...] and date-palms and syca[mores, and a]ll (types of) tr]ees, and wet [and $\mathrm{d}] \mathrm{r}[\mathrm{y}]$

${ }^{42}$ C. JOHns, Babylonian and Assyrian Laws, Contracts and Letters. T. \&T Clark, Edinburgh, 1904, p. 241. 
wood/ vegetation; and arid ground [such as there is in it, and assigned watering periods, and water and...and...; and partnership and estate rights, and .......and courtyards [...] within (it) - every place, and anything (whatsoever), s[ma]ll and la[rg]e, that is fitting for him with (regards to) these purchases, sun(ny areas) and where shed falls". P. Yadin 3 for example is a deed of sale dated to the 28th year of Rabel II and it is a deed of sale of a palmgrove. This sale includes the land and its trees in addition to the weekly irrigation timings, and indicates that their turn will be for half an hour on the first day of every week forever: "including the irrigation-ditches and the assigned watering periods, a half of one hour on the first day of the week and every [wee]k for ever".

\section{d) Items and parts that are included in the sale}

The Wādī Mūsā deeds of sale refer to the items and parts that are included in the sale. Document 2 states that "the purchaser may water from the new waters of eț-Twaisāt, as it was the case of my previous sale which was conditional to watering from my portion with my brother the bin 'Alī eț-Ṭwaisī, Moḥammad, 'Isā and Ibrahim".

\section{e) Quantitative information}

The following part contains quantitative characteristics such as the amount of land, the measurement units most often used in addition to the price and definition of coins. The price of the property is written at the top of the document in numbers and letters and repeated again in letters inside the texts. Sometimes we find descriptive methods of measurements e.g. the quantity of grain needed to sow a particular plot of land. The section is followed by the payment of the price and confirmed that "the above-mentioned amount was paid in full" either in cash or in materials. Similar tradition is found in the Nabataean texts which mention dmy mgmr "complete price" 43 .

\section{f) consciousness of the seller and purchaser}

The Aramaic deeds of sale contain hints that the seller and the purchaser were conscious, the contract was prepared by their will without any forces and it was done according their wills and this is indicated by the formula "tyb lbby" "my heart is satisfied" 44 . This is not attested in Nabataean documents but occurs in the Wādi Mūsā documents. In document 3 we find that the parties "were not forced to do this sale".

43 See P.Yadin 2, line 9.

${ }^{44} \mathrm{R}$. WestbrooK, "The Phrase 'His Heart is Satisfied' in Ancient Near Eastern Legal Sources», in Journal of the American Oriental Society 111 (1991), p. 219-224. 


\section{g) Defenition clause}

Defenition clause appears in most of the documents. It is the primary obligation of the seller to appear in court and to defend the claims brought against the purchaser and such defenition clause occurs in the Neo-Babylonian and Aramaic documents and this is a specific clause to protect the right of the purchaser ${ }^{45}$. It is one of the most important elements in the Ancient Near Eastern deeds of sale is the defenition clause ${ }^{46}$. It is a guarantee that gives the right to the vendor to make a declaration in the case of a dispute that the property has been sold legally and to confirm that it belongs now to the purchaser. Another correspondence is attested in relation to the giving of the absolute authority to the buyer, to use the properties in the way that he wishes: "to buy and to sell, to pledge and to bequeath and to grant as a gift, and to do with these purchases all that he wishes" ${ }^{47}$, which is unlimited in time "from this day and forever". Locutions resembling this one are common in Aramaic". "No lawsuit and no contest, and no oath" is a phrase quite common in ancient legal texts as well as in the Nabataean papyri. The first two words l' din $w l$ ' $d b b$ are attested in other forms in a Demotic deed of sale which reads "I will make it without citing any patent (?), any word in the land against thee" ${ }^{49}$. The word dyn is attested widely in Aramaic meaning "to judge" 50 . The second word $d b b$ is also attested in Akkadian and Official Aramaic ${ }^{51}$. Document 2 sates ""and in order to avoid any dispute I wrote this agreement to them to express my acceptance" and document 1 mentions "absolute sale and new possession, and he has the right to do with these lands all that he wishes".

\section{h) Witnesses}

Witness names are at the bottom of the document and their numbers are undetermined and depends on the importance of the document. As illiteracy was common names and thumbimpression are instead of the signature and sometimes personal seals of well-known personalities were added and they are cases where someone singed on behalf of another one. In several documents from Wādī Mūsā we find that some persons signed on the behalf of others. In the Nabataean document the writer used the

\footnotetext{
${ }^{45}$ Y. YARON, "Note on A Judaean Deed of Sale of a Field», in Bulletin of the American Schools of Oriental Research 150 (1958), p. 26-28.

${ }^{46}$ J. GREENFIELD, "The "Defension Clause" in some Documents from $\mathrm{Na}$ hal Hever and Nahal Se'elim». in Revue de Qumran 15 (1992), p. 467-71.

${ }^{47}$ P. Yadin 2, line 9.

${ }^{48}$ J. RABINOWITZ, Jewish Law: Its Influence on the Development of Legal Institutions, Bloch Publishing Company, New York, 1956, p. 135.

${ }^{49}$ J. RABINOWITZ, p.107.

${ }^{50}$ DNWSI, p. 246.

${ }^{51}$ DNWSI, p. 237.
} 
term ktb $y d h$ to confirm that the writer surly write in his hand and no one on behalf of him. Witnesses from different tribes to confirm the validity of the contract especially in cases of watering periods and trees sold in the contract. Nabataean papyri provide cases where someone else signed of one's instead. Hebrew, Aramaic, and Nabataean papyri uncovered in the Wādī Habra provide evidence of the practice of enlisting another person to sign a legal document in one's instead ${ }^{52}$. Different numbers of witnesses are enlisted.

\section{i) Validation of the document}

Documents were validated by the signature of the issuer. The signatures are placed on the bottom left-hand of the document, personal seals were also used. The last part of the documents refer to the personality and post of the issuer.

\section{j) The date}

One of the major elements of the deeds of sale is the date. In the documents from Wādī Habra we read dating was made according to the reignal year of the king and this includes the day, the month and the year. The dating system used in the Wādi Mūsā documents was Hijri. After the establishment of the Transjordan emirate in 1921, the legal documents were dated both to Hijri and AD. Some of the contracts are undated.

\section{k) Offical debenature}

There is an official debenture to be issued in the Ottoman language to the new owner of the property. These official documents were housed normally at the nearest governmental office and includes the serial number of the document, date, the administrative district that the sold property belongs to, borders, price, determination of the taxes paid upon selling or conveying the land, signatures and stamps. Similar traditions most likely existed in Nabataea. One of the Nabataean inscriptions found in Hegra refers to a nsht, which might mean a "copy" of a legal document that is kept in an archive of byt qys" "the temple of Qaysha" 53 .

\section{1) The place where the contract was made}

Both types of documents mention the name of the place where the contract was made. Most of the Nabataean documents were written in Mahōzā which lies in the district of Zoar which is located in the vicinity of modern Aș-Ṣāfi south of the Dead Sea. The Wādī Mūsā deeds of sale were written in Wādī Mūsā.

${ }^{52}$ Y. Yadin, J. GreEnfIELd, A. Yardeni, B. LeVIne, p. 11.

53 J. HEALEY, "Sources for the Study of Nabataean Law», New Arabian Studies 1 (1993), p. 36. 


\section{Concluding remarks}

1. Many of the elements of the Nabataean deeds of sale are the same of the Ottoman Wādī Mùsā.

2. The Nabataean deeds of sale were more detailed which indicate a strong legal authority meanwhile the Late Ottoman ones are short which indicates that the common legal Aramaic traditions that existed in this region around the Christian era did not continue to develop.

3. These deeds prove that that some of the Nabataean Aramaic legal traditions remained alive in this region and confirm that some of the legal practices, in terms of the patterns and contents, did not cease after the end of the Nabataean kingdom in AD 106. It is apparent from the contents of these documents that they formed a continuous part of the Ancient Near Eastern and Syrian common law. 


\section{Appendix}

\section{English Translation of Document 1}

900

Junayh amount $/ 2$

Only two Palestinian Junayh

Lands description and boundaries

The first one: land plot at al-Bou'bou' al-'Liyā whose boundaries are: to the south 'Isā al-Ṣāne', Halīil al-Helālī to the east, 'Isā alȘāne' and his brothers to the west and to the north the sons of Ḥmaydān.

The second one: the lower one whose boundaries are: water channel from the west, the sons of Helāl to the south, the sons of Hamdān and Sulaimān the sons of Hamdān to the south and alḤasanāt and al-Nașarāt to the north

The third one: Tal'at Jum'ah whose boundaries are: the sons of Helāl to the west, Halīl al-Helālì to the south, Halīl al-Helālī to the east and al-Nașarāt Am at- ${ }^{3} \overline{\mathrm{u}} \mathrm{q}$ to the north.

On the date written below, I, the undersigned 'Alī Bin Sālem alHelālāt and my sons Moḥammad and Mūsā sold what belongs to us in the above-described lands: what belongs to us in Ardh alBou'bou' and Tal'at Jum'ah in the boundaries and descriptions written above to 'Alī Halīl Moḥammad al-Helālī with two Palestinian Junayh, only absolute sale and new possession, and he has the right to do with these lands all that he wishes and the price has been received in full and cash in the presence of witnesses and Allah is the best witness.

Witnesses who witnessed the sale (names and signatures or thumb impression)

Stamp and date $(2 / 10 / 1937)$ 


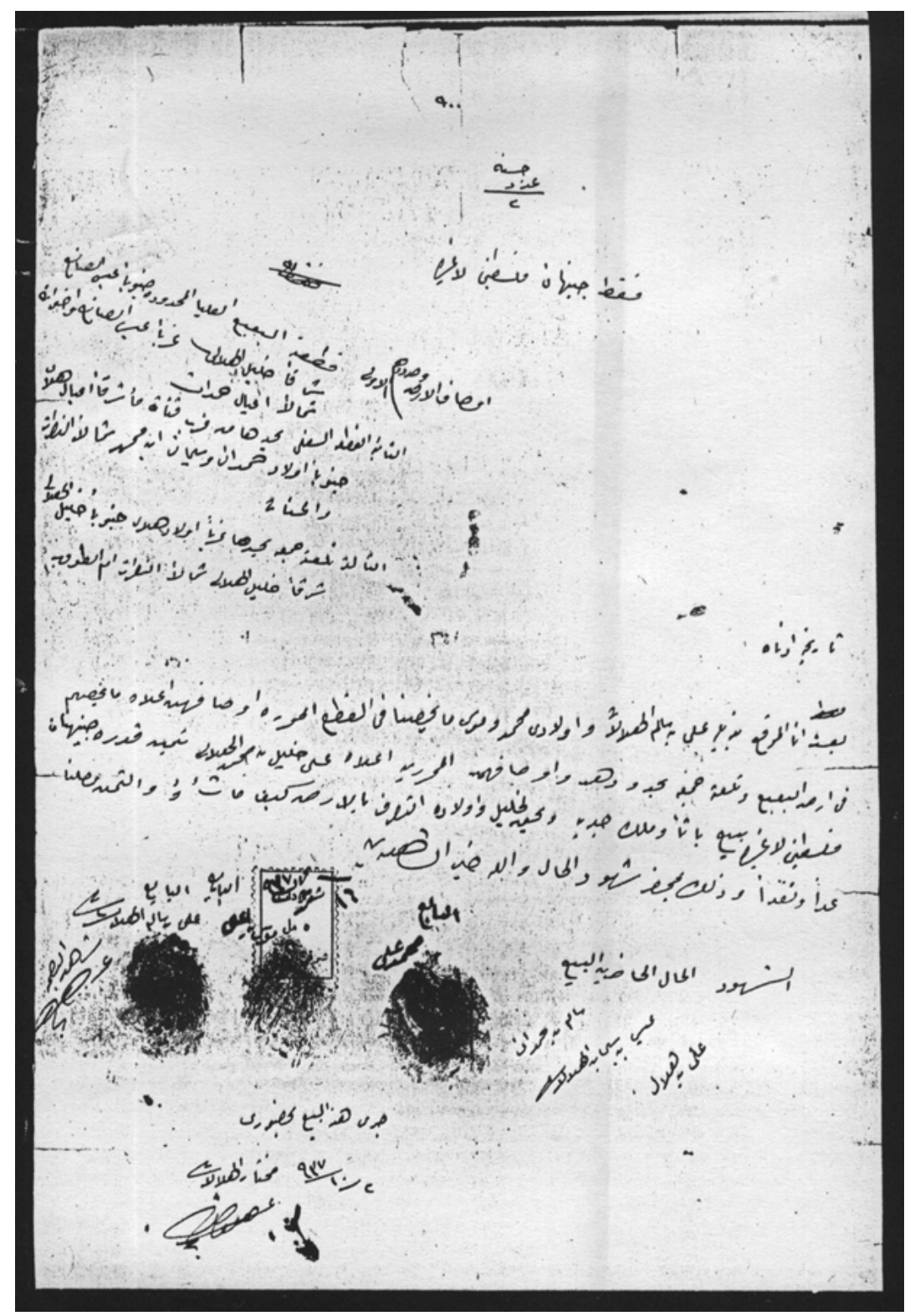

Figure 1 : Document 1 


\section{English Translation of Document 2}

Symbol of the scribe (unclear?)

27 Turkish Riyal only

Party one: Hualīl bin 'Alī eț-Ṭwaisī

Party two: Halīl bin Moḥammad al-Helālī and his son Sulaimān, and both of them are from Wādī Mūsā

I the undersigned, Halîl bin 'Alī eț-Ṭwaisī, decree that I sold my portions in the lands of the mosque which is bordered to the east by 'Ațallhah et-Twaisī and reached (the land) of my brother Ibrahim and to the north (the land) of 'Atallhah, to the east is the public road, and to the south 'Isā eț-Ṭwaisī and Ibrāhīm, and this sale includes various trees.

I admit and confess that the sale was made upon my satisfaction, acceptance and the consultation of my brothers and relatives (who are witnesses) for a period of approximately 32 years, the purchaser may water from the new waters of et-T Twaisāt, as it was the case of my previous sale which was conditional to watering from my portion with my brother the bin 'Alī eț-Ṭwaisī, Moḥammad, 'Isā and Ibrahim.

And in order to avoid any dispute I wrote this agreement to them to express my acceptance and the receiving of the whole absolute amount after the consultation of my brothers and relatives to whom I explained that watering may be from the watering portion of et-T Twaisī which belongs to the sons of 'Alī et-T Twaisī forever, and we allowed witnesses to witness and Allah is the best witness.

Witness 'Odeh bin Mūsā al-Shoulī

Witness Hārūn bin Aḥmad (?)

Witness 'Al̄̄ Al-Shoulī

Names and signatures of the seller and purchaser

Official stamp, Date 1947 


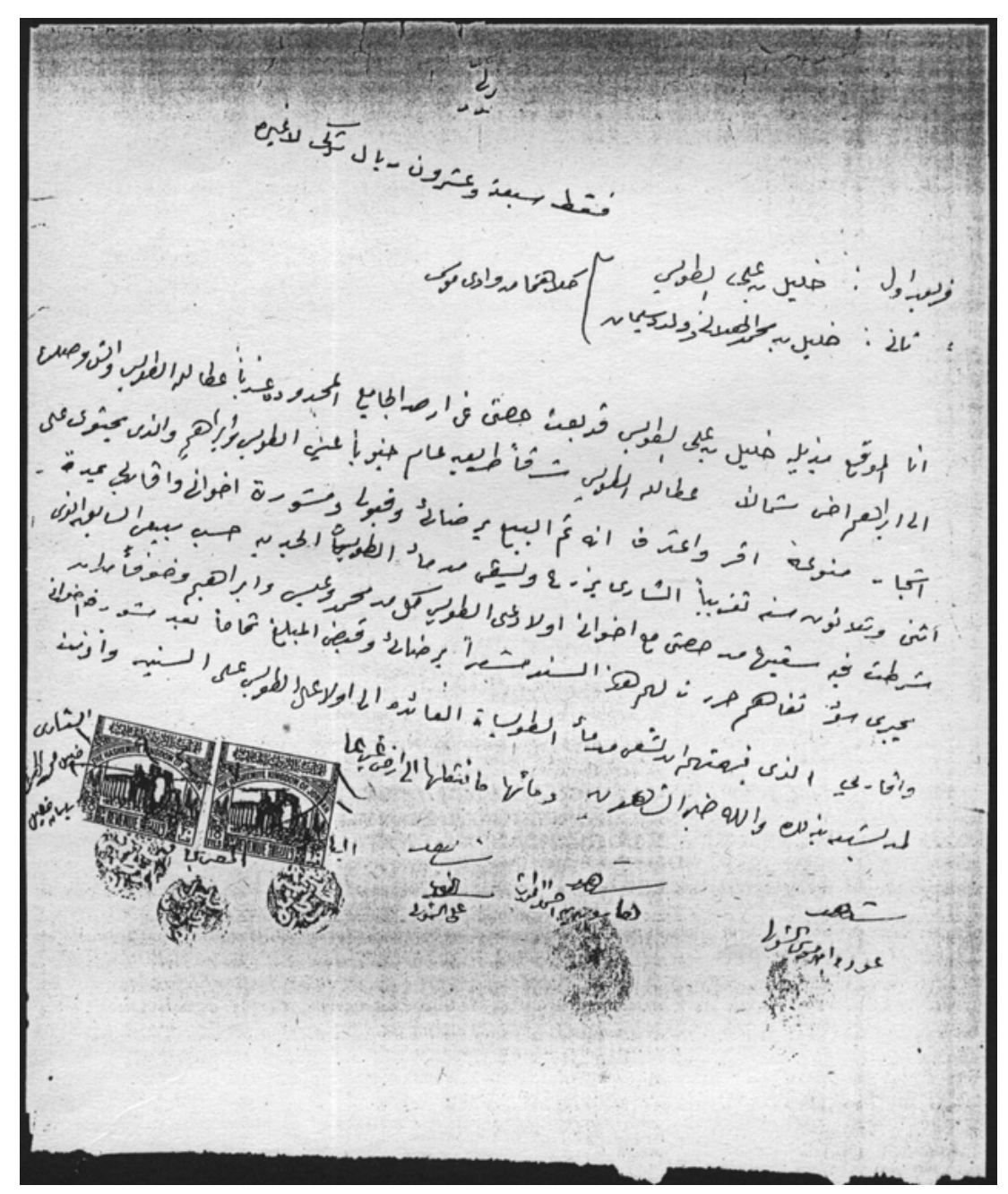

Figure 2 : Document 2 


\section{English Translation of Document 3}

Symbol of the scribe 50

The first party: Mğanam bin Ğānim from the inhabitants of Wādī Mūsā of the Shourur tribe.

The second party: Mūsā bin Sālim eț-T waisī from the inhabitants of Wādī Mūsā too.

The first party Mğanam bin Ğānim from the inhabitants of Wādī Mūsā of the ash-Shrūr tribe has sold to the second party Mūsā bin Sālim eț-Ṭwaisī in the presence of his son Mūsā bin Mğanam bin $\breve{G}$ annim all the third land which is two donums bordered to the north by Sālim al-'Uaināt, to the east by Mūsā eț-Ṭwaisī and the public road to the west and south for the amount of 15 Turkish Majī $\overline{1}$, and this sale was absolute and final and they were not forced to do this sale and upon that we agreed, the purchase was handled, and the first party allowed the second one to do whatever they may want (in this purchase) and accordingly this contract was made in a case of a dispute in the attendance of the witnesses signed below.

Witness Moḥammad al-Falāhāt bin Diblek

Witness 'Alī Al- Sulaimān al-Helālī

Witness 'Alī bin Jād Helālāt

Signature of the seller and purchaser and official stamps

23.10 .1904 


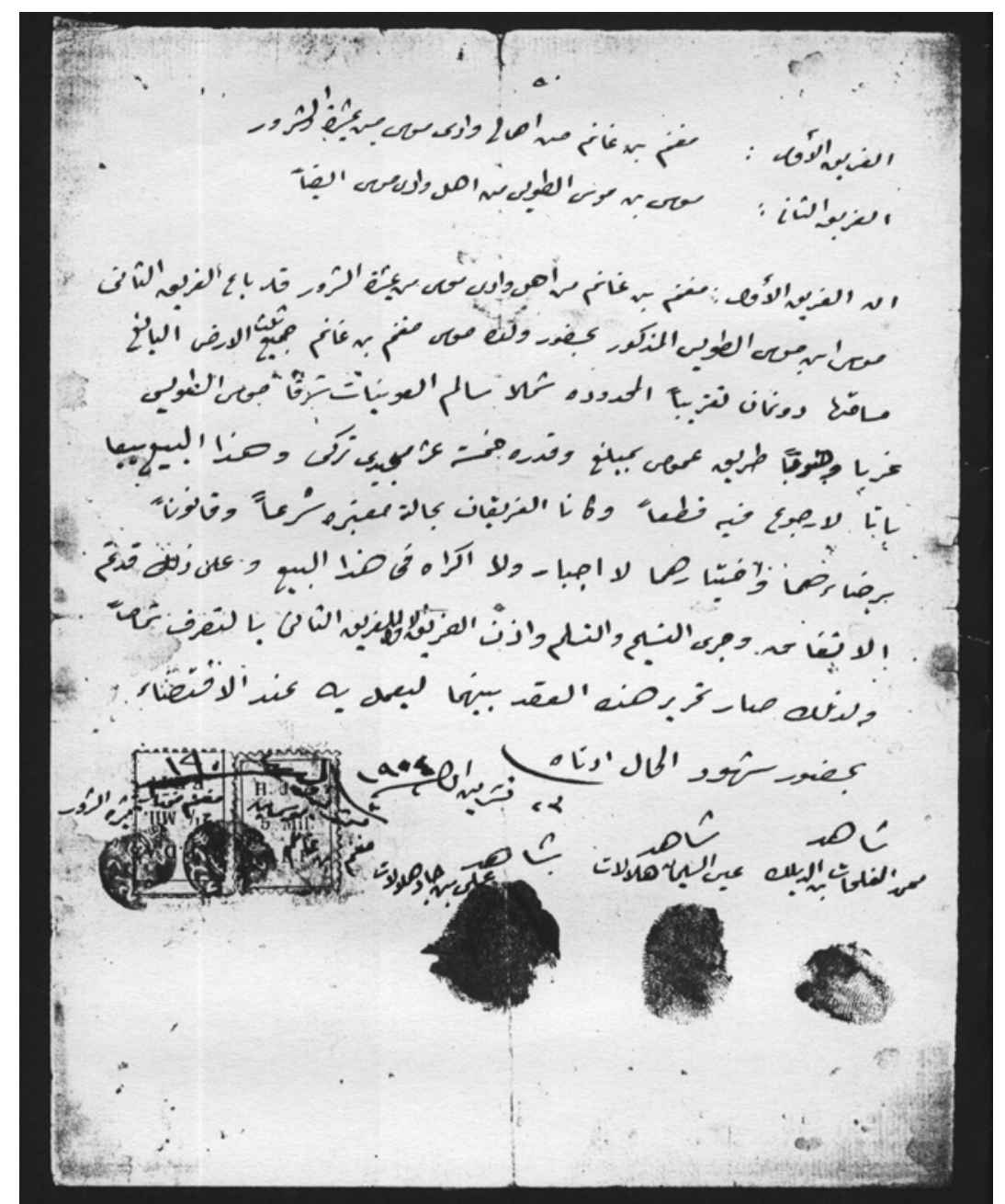

Figure 3 : Document 3 
